\title{
In vitro direct multiplication of Viola canescens Wall. ex Roxb.: An important medicinal plant
}

\author{
Kavita Rani, Rameshwar Groach $*$, Jitender Sharma** and Narender Singh \\ Department of Botany, Kurukshetra University, Kurukshetra-136119, Haryana, India \\ *Departemnt of Botany, Mukand Lal National College, Yamuna Nagar-135001, Haryana, India \\ **Department of Biotechnology, Kurukshetra University, Kurukshetra-136119, Haryana, India
}

\begin{tabular}{|c|c|}
\hline Article Info & Abstract \\
\hline rticle history & \multirow{10}{*}{$\begin{array}{l}\text { The present study investigated the different sterilization procedures for seed explants of Viola canescens } \\
\text { Wall. ex Roxb. collected from a wild-grown plant on Morni Hills, Panchkula and in vitro frequency of } \\
\text { multiple shoot regeneration of cotyledonary node having both cotyledons. Maximum per cent aseptic } \\
\text { germination of healthy seeds were obtained when seeds were treated with bavistin and streptomycin for } 10 \\
\text { min followed by a quick immerse in } 70 \% \text { ethanol and finally sterilized with } 1.0 \% \mathrm{HgCl}_{2} \text { for } 5 \mathrm{~min} \text { and } \\
\text { cultured on half-strength MS media containing } 0.5 \mathrm{mg} / \mathrm{GA} \text {. Effect of three different cytokinins (KIN, BAP } \\
\text { and TDZ) alone and in amalgamation with auxin (NAA) were evaluated to investigate the frequency of in } \\
\text { vitro shoot multiplication from cotyledonary node having both cotyledons. The highest average number } \\
\text { of shoots }(10.6 \pm 0.547) \text { and maximum average shoot length }(6.7 \pm 0.101 \mathrm{~cm}) \text { was obtained on MS media } \\
\text { fortified with BAP }(2.0 \mathrm{mg} / \mathrm{l})+\mathrm{NAA}(0.5 \mathrm{mg} / \mathrm{l}) \text {. Half strength MS medium augmented with IBA }(2.0 \mathrm{mg} / \\
\text { 1) reported best for rooting of regenerated shoots with } 86.66 \% \text { efficiency. Finally, in the field setting, } \\
\text { nearly } 85 \text { per cent of regenerated plantlets were able to thrive successfully. }\end{array}$} \\
\hline ed 10 October 2021 & \\
\hline 27 Nov & \\
\hline ed 29 Nov & \\
\hline Published Online & \\
\hline eywords & \\
\hline Viol & \\
\hline cinal & \\
\hline ion & \\
\hline ination & \\
\hline
\end{tabular}

\section{Introduction}

The Himalayas storehouse has incredible plant biodiversity, with many endemic, endangered, threatened and vulnerable plant herbs (Badola and Aitken, 2003). Many of these herbs have been well recognized to cure various diseases in traditional system of medicines (i.e., Ayurveda, Unani, etc.) and shows better or comparable relief with allopathic medicines (Sagar et al., 2018; Ansari et al., 2019). $V$. canescens commonly known as Banafsha or Himalayan White Violet is one of the endangered species of Himalayas region (Masood et al., 2014). It belongs to the Violaceae family, consisting of 20 genera and about 800 species (Chandra et al., 2015). This species is spread worldwide in countries such as India, Pakistan, Bhutan and Nepal (Chandra et al., 2015; Khajuria et al., 2019). It is restricted mainly to the mountainous areas of the temperate and tropical zones (Singh et al., 2005; Masood et al., 2014). It is a perennial prostrate plant, which thrives especially in sciophile environments (Muhammad et al., 2012; Mc Cauley and Jr., 2013).

In India, $V$. canescens, mainly prevalent in some cold arid deserts of northwest Himalaya, i.e., Pangi valley of Chamba district in Himachal Pradesh (Trans Himalayan zone) and Garwal region of Uttarakhand at an altitude of 1600-2000 m (Rana et al., 2014; Masood et al., 2014). Some other regions of Uttarakhand (Nainital catchment area and Nanda Devi National Park) also exhibited the presence of V. canescens (Dua et al., 2011; Shah et al., 2014).

Corresponding author: Dr. Rameshwar Groach Departemnt of Botany, Mukand Lal National College, Model Town, Yamuna Nagar-135001, Haryana, India

E-mail: rameshwar.groach@mlncollegeynr.ac.in Tel.: +91-9729793030

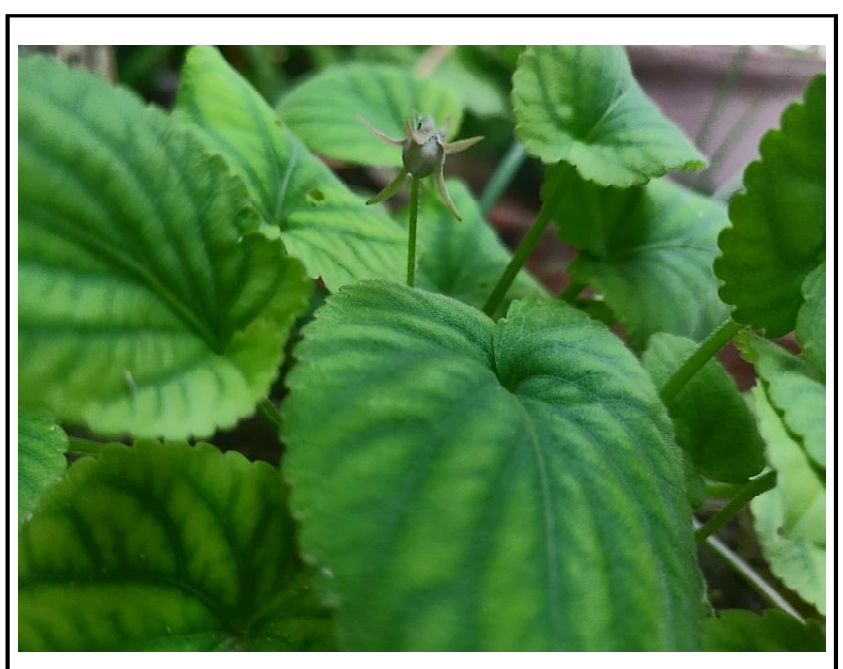

Figure 1: Closeup view of $V$. canescens plant showing fruiting.

This plant is normally present in Pakistan in all temperate Himalayan ranges at an altitude of about $2000 \mathrm{~m}$ (Shinwari and Shinwari, 2010; Masood et al., 2014; Kumar and Digvijay, 2014). V. canescens prefer to grow in the habitat of four other herbs such as Euphorbia wallichii, Fragaria indica, Podophyllum emodi with Polygonum (Saima et al., 2009; Masood et al., 2014). Another group affiliation investigated in Ayyubia National Park affirmed the foundation of $V$. canescens along side Pinus wallichiana and Geranium nepalense affiliation spread over the range 2282 meters and it runs up to 2300 meters AMSL or here and there marginally above at some different regions (Raja et al., 2014; Masood et al., 2014). 
In traditional ethnomedicinal systems, $V$. canescens is used to medicate various conditions such as bronchitis, cold, cough, flu, cancer of the throat, respiratory tract problems, eczema, epilepsy, gastric acidity, pyrexia, dysentery, rheumatism etc, (Hamayun et al., 2006; Abbasi et al., 2010; Hussain et al., 2011; Rani et al., 2013; Rana et al., 2014; Razzaq et al., 2015; Khajuria et al., 2019). The plant is used to treat various nervous problems (Adnanand Hlscher, 2010) and also reported to have astringent, antipyretic, carminative, demulcent, diaphoretic, anticancerous and purgative properties. Solvent extracts of $V$. canescens, exhibited hepatoprotective activity due to its antioxidants and membrane stabilization ability (Khan et al., 2017). Such therapeutic effects of plants have been linked to study over time owing to the existence of some secondary metabolites, such as saponins, glycosides and methyl salicylate (Barkatullah et al., 2012) and the presence of some cyclotides responsible for its antimicrobial properties (Burman et al., 2014).

Due to its high ethnomedicinal values, $V$. canescens was unsustainably overharvested from wild, bringing it into the criteria of being "vulnerable to extinction" (Abbasi et al., 2011). The survival of this species is at risk in the future, because of increasing need of this plant for medicinal use (Masood et al., 2014). The conservational status of $V$. canescens was found endangered in Battagram district of Pakistan (Haq, 2011; Masood et al., 2014), rare or vulnerable in Swat valley of Pakistan, vulnerable in Dir Kothistan valley (Jan et al., 2014) due to its over collection. Utilizing various conservation strategies and saving this valuable medicinal wealth from extinction is the need of the hour (Masood et al., 2014).

Micropropagation is an efficiently proven method for restoration of the traditional treasure of biodiversity. Conservation of other Viola species such as V. baoshanensis (Li et al., 2010), V. patrinii (Chalageri and Babu, 2012), V. odorata (Naeem et al., 2013; Mokhtari et al., 2016) and V.pilosa (Soni and Kaur, 2014) has been done with many mass multiplication tissue culture protocols. But, in V. canescens, only indirect organogenesis tissue culture work has been reported by Khajuria and Bisht (2018). Khajuria et al. (2019), but direct organogenesis for mass multiplication of $V$. canescens has not performed yet. However, the possibility of genetic variability, i.e., gene mutations or epigenetic changes (somaclonal variations) is theoretically more in callus mediated organogenesis as compared to direct organogenesis (Zayova et al., 2010; Krishna et al., 2016). Cotyledonary node is a young meristematic portion of seedling were removed aseptically and used as source of explant for in vitro plant regeneration through direct organogenesis (Gambley and Dodd, 1990; Venkatachalam et al., 2018). So, the present report contains skilled efforts for its conservation and cultivation of a large number of clones with maintaining elite genotypes selected for their superior characteristics. Therefore, an in vitro protocol that can effectively increase stock or commercial scale multiplication of $V$. canescens with less chance of somaclonal variations is urgently needed.

\section{Materials and Methods}

\subsection{Plant material collection}

Seeds of V. canescens were gathered from Morni hills Panchkula, Haryana in the month of June to July. All seeds were collected from different locations of Morni hills and stored at $4^{\circ} \mathrm{C}$ temperature for up to 10 days from the date of collection. All seeds were hand graded to get the undamaged and healthy seeds followed by viability testing by flotation method (Ajiboye et al., 2011). Then, for $2 \mathrm{~h}$ the seeds were dried. Finally, good quality seeds was selected for further experiment.

\subsection{Surface sterilization regimes for seeds and in vitro culturing}

Pretreatment was given similar to all sets, after washing with flowing tap water for half an hour to eliminate all adhering dust particles, followed by washing with Tween 20 solution (i.e., 2-3 drops in 200 $\mathrm{ml}$ DDW). After rinsing 5-6 times with double distilled water (DDW), seeds were dipped in $0.1 \%$ solution of bavistin and streptomycin for $10 \mathrm{~min}$, then again rinsed 5 times with DDW. Afterward, explants quickly dipped in $70 \%$ ethanol and washed 3 times with sterilized DDW, followed by three independent sterilization experiments performed under aseptic conditions with hydrogen peroxide $\left(\mathrm{H}_{2} \mathrm{O}_{2}\right)$, sodium hypochlorite $(\mathrm{NaOCl})$ and mercuric chloride $\left(\mathrm{HgCl}_{2}\right)$, at various strength of solutions such as $0.1 \%, 0.5 \%, 1.0 \%(\mathrm{w} / \mathrm{v})$ for $5 \mathrm{~min}$ (Table 1.). Finally, seeds were rinsed with autoclaved DDW for 4-5 times to remove all adhering traces of $\mathrm{H}_{2} \mathrm{O}_{2}, \mathrm{NaOCl}$ and $\mathrm{HgCl}_{2}$. Then, the treated seeds were aseptically inoculated to petri plates (BOROSIL) containing half strength MS media supplemented with $\left(0.5 \mathrm{mg} / \mathrm{l} \mathrm{GA}_{3}\right)$ for germination.

\subsection{Culture media and conditions}

Half strength or full strength MS (Murashige and Skoog, 1962) media fortified with or without various concentration of plant growth regulators, $3.0 \%(\mathrm{w} / \mathrm{v})$ sucrose and solidified using $0.8 \%(\mathrm{w} / \mathrm{v})$ agar (HI Media labs, India) as shown in Table-1, Table-2 and Table-3 were used in present experiment. The $\mathrm{pH}$ of the medium was adjusted between 5.79-5.81 using $0.1 \mathrm{~N} \mathrm{NaOH}$ or $0.1 \mathrm{~N} \mathrm{HCl}$ former to autoclaving at $\mathbf{1 5} \mathbf{~ p s i}$ for $20 \mathrm{~min}$. Cultures were maintained in dark for initial 3 days in culture room sustained at temperature $25 \pm 2{ }^{\circ} \mathrm{C}$ and then transferred back to culture room at same temperature, under an $8 / 16$ hour light/dark photoperiod cycle provided with a photosynthetic photon flux density (PPFD) of $70 \mu \mathrm{mol} \mathrm{m}^{-2} \mathrm{~s}^{-1}$ and about $60-80 \%$ humidity. All aseptic manipulations were carried out underaseptic environment of laminar airflow chamber.

\subsection{Explant preparation and shoot multiplication}

Seed germination began after 1 weeks of inoculation and per cent aseptic seeds germinated and per cent contaminated were recorded after 3rd weeks. Cotyledonary nodes (with both cotyledons) as an explant were aseptically excised from the seedlings between 3-4 week after inoculation and cultured on MS medium augmented with various strength solution of plant growth regulators (Table 2). MS nutrient media devoid of any plant growth regulator was taken as control. Per cent germination, average number of days required for bud break, average number of shoots, average shoot length and comparative response of culture was recorded (Table 2) upto $5^{\text {th }}$ week of culture.

\subsection{In vitro rooting of micropropagated shoots}

The regenerated in vitro multiple shoots were withdrawn and relocated to a medium of half and full strength MS augmented with or without various concentrations $(1.0,2.0$ and $3.0 \mathrm{mg} / \mathrm{l})$ of rooting hormones (IAA, IBA) to stimulate in vitro root induction. Cultures were initially maintained in dark for 3 days after inoculation and then moved back to culture room at temperature $25 \pm 2{ }^{\circ} \mathrm{C}, 8 / 16 \mathrm{~h}$ light/dark photoperiod cycle, PPFD of $70 \mu \mathrm{mol} \mathrm{m}^{-2} \mathrm{~s}^{-1}$ and about 60$80 \%$ humidity. The per cent root regeneration, average number of days required for root induction, Mean number of roots produced 
per shoot, mean length of root and culture response was recorded up to four week of culture.

\subsection{Data analysis}

Data was analysed using software SPSS 16.0. The impact of various treatments was evaluated using a one-way variance study (ANOVA) and the disparity between their thresholds was measured using the post-hoc Duncan Multiple Range Test (DMRT) at $p<0.05$ (Duncan, 1955). Values have same letters are non-significant.

\section{Results}

3.1 Effect of different concentration of different sterilants $\left(\mathrm{NaOCl}, \mathrm{H}_{2} \mathrm{O}_{2}\right.$ and $\mathrm{HgCl}_{2}$ ) with various exposer time on seed explants

$\mathrm{H}_{2} \mathrm{O}_{2}, \mathrm{NaOCl}$ and $\mathrm{HgCl}_{2}$ were the three sterilants at various concentrations $(0.1 \%, 0.5 \%$ and $1.0 \%)$, were investigated to standardize for the best protocol for higher in vitro aseptic germination (Table 1). The maximum per cent aseptic germination ( $80.0 \pm 02.54)$ and higher comparative culture response was reported with $\mathrm{T} 9$ treatment, i.e., $1.0 \% \mathrm{HgCl}_{2}$ for $5 \mathrm{~min}$ with lowest $(07.3 \pm 0.816)$ per cent contamination among all the tested treatments. T1 treatment $\left(0.1 \% \mathrm{H}_{2} \mathrm{O}_{2}\right)$ reported the lowest $(03.3 \pm 0.408)$ per cent aseptic germination and highest per cent contamination $(91.6 \pm 01.08)$. Progressive increases in per cent aseptic germination (or progressive decrease in per cent contamination) was reported with increase of respective concentrations $(0.1 \%$ to $1.0 \%)$ of all the three sterilants tested. However, comparative among the three different chemical sterilants tested $\left(\mathrm{H}_{2} \mathrm{O}_{2} \mathrm{NaOCl}\right.$ and $\left.\mathrm{HgCl}_{2}\right)$, the $\mathrm{H}_{2} \mathrm{O}_{2}$ reported higher per cent aseptic germination followed by $\mathrm{NaOCl}$ and lowest with $\mathrm{H}_{2} \mathrm{O}_{2}$ ).

\subsection{In vitro establishment and multiplication}

The cotyledonary nodes with cotyledons, excised from 3-4 week old seedlings of $V$. canescens and cultured on MS media with or without growth regulators revealed various responses (Table 2). Cotyledonary node did not show any morphogenic response on medium rid of growth regulators (Control). Medium supplemented with BAP, KIN and TDZ promoted bud differentiation from the cotyledonary node but medium supplemented with BAP was found more efficient for initiation and subsequent shoot proliferation (76.66 $\%$ ) as compared to KIN and TDZ. Initially, a small callus knob was formed at the base of the cotyledonary node. Soon after small protuberances arise in the cotyledonary nodes which further developed into elongated slender shoots. Protuberances kept on emerging upto the $5^{\text {th }}$ week of culture. The frequency of shoot bud development and the number of shoots per explant increased with increasing concentration of KIN, BAP and TDZ, respectively (Table 2). High concentration of BAP $(2.0 \mathrm{mg} / \mathrm{l})$ showed maximum response $(76.66 \%)$ of bud regeneration from cotyledonary nodes among all the plant growth regulators tested individually. TDZ showed less response towards shoot regeneration as compare to KIN and BAP. However, comparative among the three plant growth regulators tested individually (KIN BAP and TDZ), the BAP reported higher per cent regeneration in lesser number of average days required for bud break with highest number of average shoots as well as longer average shoot length followed by KIN and then TDZ.

Table 1: Effect of various surface sterilization treatments, being followed for disinfection of seeds of $V$. canescens and inoculatedon half strength MS medium augmented with $(0.5 \mathrm{mg} / \mathrm{l} \mathrm{GA})$ for germination

\begin{tabular}{|c|c|c|c|c|c|}
\hline Chemicals & Treatments & Concentration (\%) & $\%$ Contamination & \% Aseptic Germination & Response \\
\hline \multirow[t]{3}{*}{$\mathrm{H}_{2} \mathrm{O}_{2}$} & $\mathrm{~T} 1$ & 0.1 & $91.6 \pm 01.08^{\mathrm{i}}$ & $03.3 \pm 0.408^{\mathrm{h}}$ & + \\
\hline & $\mathrm{T} 2$ & 0.5 & $88.3 \pm 02.04^{\mathrm{h}}$ & $10.0 \pm 0.707^{\mathrm{g}}$ & + \\
\hline & T 3 & 1.0 & $71.6 \pm 02.04^{\mathrm{f}}$ & $15.0 \pm 0.707^{\mathrm{f}}$ & ++ \\
\hline \multirow[t]{3}{*}{$\mathrm{NaOCl}$} & $\mathrm{T} 4$ & 0.1 & $79.3 \pm 0.816^{g}$ & $11.6 \pm 0.408^{g}$ & + \\
\hline & T 5 & 0.5 & $42.3 \pm 0.408^{\mathrm{e}}$ & $22.3 \pm 0.408^{\mathrm{e}}$ & ++ \\
\hline & $\mathrm{T} 6$ & 1.0 & $23.3 \pm 0.816^{\mathrm{c}}$ & $44.6 \pm 0.408^{c}$ & +++ \\
\hline \multirow[t]{3}{*}{$\mathrm{HgCl}_{2}$} & $\mathrm{~T} 7$ & 0.1 & $28.0 \pm 0.707^{\mathrm{d}}$ & $37.0 \pm 01.22^{\mathrm{d}}$ & +++ \\
\hline & T 8 & 0.5 & $15.6 \pm 01.08^{\mathrm{b}}$ & $57.3 \pm 0.408^{\mathrm{b}}$ & +++ \\
\hline & T 9 & 1.0 & $07.3 \pm 0.816^{\mathrm{a}}$ & $80.0 \pm 02.54^{\mathrm{a}}$ & ++++ \\
\hline
\end{tabular}

Data generated from three independent experiments $(n=100)$, where, “ \pm ” values represent mean standard deviation (SE).

A combinatory effect of auxin and cytokinin was also observed for regeneration potential and multiple shoot induction (Table 2). Augmentation of NAA $(0.5 \mathrm{mg} / \mathrm{l})$ to MS medium in combination with $2.0 \mathrm{mg} / \mathrm{l}$ of BAP, TDZ and KIN significantly increased the shoot multiplication response. Per cent explant regeneration $(83.33 \%)$, response, average number of shoots $(10.6 \pm 0.547)$ and average shoot length $(6.7 \pm 0.101)$ was reported highest in media supplemented with $2.0 \mathrm{mg} / \mathrm{l} \mathrm{BAP}$ and $0.5 \mathrm{mg} / \mathrm{l} \mathrm{NAA}$ among all the medias (Table 2), observed after $5^{\text {th }}$ week of culturing. On visual observation, it was noticed that cultures in MS media supplemented with $2.0 \mathrm{mg} / \mathrm{l}$ BAP and $0.5 \mathrm{mg} / \mathrm{l} \mathrm{NAA}$ produce healthy shoots and larger expanded leaf areas as compared to basal medium augmented with BAP, TDZ and
KIN individually. Increasing the concentration of TDZ and BAP reduced the average shoot number (data not mentioned) and showed vitrification symptoms. However, comparative among the combination of $0.5 \mathrm{mg} / \mathrm{l}$ of NAA with $(2.0 \mathrm{mg} / \mathrm{l}$ of KIN BAP and TDZ), the BAP reported BAP + NAA reported best results followed by KIN+NAA and then TDZ+NAA.

\subsection{In vitro rooting}

Regenerated shoots were excised and transferred to the half and fullstrength MS medium with or without fortification with auxin (IAA and IBA) at different concentrations for root induction after $5^{\text {th }}$ week of shoot regeneration culture (Table 3). Root started emerging in 
inoculated shoots after one week of inoculation depending on the auxin type (IBA and IAA) and concentration supplemented to the medium. The concentration of auxin played a vital role in root induction. Medium devoid of auxin did not show any root induction. Highest rooting response was found in $1 / 2$ MS medium augmented with $2.0 \mathrm{mg} / \mathrm{l} \mathrm{IBA}$, where about $86.66 \%$ culture responded with on an average root number of $5.8 \pm 1.095$ per shoot and an average root length of $2.42 \pm 0.074 \mathrm{~cm}$ with very good culture response. Half strength MS medium proved best for root induction as compared to full strength MS medium. In contrast, shoots cultured in medium enriched in IBA and IAA showed healthy root elongation without intervening callus stage.

Table 2: Effect of various concentrations of growth regulators and their combination, fortified in basal MS medium on shoot organogenesis and multiplications from cotyledonary node explant of $V$. canescens.

\begin{tabular}{|c|c|c|c|c|c|}
\hline $\begin{array}{l}\text { Medium + plant } \\
\text { growth regulators } \\
(\mathrm{mg} / \mathrm{l})\end{array}$ & Regeneration \% & $\begin{array}{l}\text { Average no. of } \\
\text { days required } \\
\text { for first bud break }\end{array}$ & $\begin{array}{c}\text { Average No. of } \\
\text { shoots } \pm \text { SE }\end{array}$ & $\begin{array}{l}\text { Average shoot } \\
\text { length } \pm \mathrm{SE} \\
(\mathrm{cm})\end{array}$ & Response \\
\hline Control (MS) & $0^{\mathrm{k}}$ & $0^{\circ}$ & $0.00^{\mathrm{i}}$ & $0.00^{\mathrm{h}}$ & - \\
\hline MS+KIN (0.5) & $60.00^{\mathrm{gh}}$ & $35^{\mathrm{k}}$ & $2.8 \pm 0.447^{\mathrm{fg}}$ & $2.7 \pm 0.450^{\mathrm{fg}}$ & + \\
\hline MS+KIN (1.0) & $56.66^{\mathrm{hi}}$ & $30^{\mathrm{j}}$ & $3.4 \pm 0.547^{\mathrm{ef}}$ & $3.7 \pm 0.482^{\mathrm{d}}$ & ++ \\
\hline MS+KIN (1.5) & $70.00^{\mathrm{de}}$ & $28^{\mathrm{i}}$ & $4.0 \pm 0.707^{\mathrm{de}}$ & $4.6 \pm 0.151^{\mathrm{c}}$ & +++ \\
\hline MS+KIN (2.0) & $73.33^{\mathrm{cd}}$ & $25^{\mathrm{g}}$ & $5.4 \pm 0.547^{c}$ & $5.5 \pm 0.151^{b}$ & +++ \\
\hline $\mathrm{MS}+\mathrm{BAP}(0.5)$ & $60.00^{\mathrm{gh}}$ & $26^{\mathrm{h}}$ & $3.4 \pm 0.547^{\mathrm{ef}}$ & $2.8 \pm 0.387^{f}$ & ++ \\
\hline MS+BAP (1.0) & $66.66^{\mathrm{ef}}$ & $24^{\mathrm{f}}$ & $3.8 \pm 0.447^{\mathrm{de}}$ & $3.2 \pm 0.355^{\mathrm{e}}$ & ++ \\
\hline $\mathrm{MS}+\mathrm{BAP}(1.5)$ & $73.33^{\mathrm{cd}}$ & $19^{d}$ & $4.2 \pm 1.09^{\mathrm{de}}$ & $3.9 \pm 0.326^{\mathrm{d}}$ & +++ \\
\hline MS+BAP (2.0) & $76.66^{\mathrm{bc}}$ & $17^{\mathrm{c}}$ & $6.0 \pm 0.707^{\mathrm{bc}}$ & $4.5 \pm 0.135^{c}$ & +++ \\
\hline MS+TDZ (0.5) & $33.33^{j}$ & $45^{\mathrm{n}}$ & $1.0 \pm 1.000^{\mathrm{h}}$ & $2.3 \pm 0.204^{\mathrm{g}}$ & + \\
\hline MS+TDZ (1.0) & $50.00^{\mathrm{i}}$ & $42^{\mathrm{m}}$ & $2.2 \pm 0.447^{g}$ & $2.6 \pm 0.178^{\mathrm{fg}}$ & + \\
\hline MS+TDZ (1.5) & $53.33^{\mathrm{hi}}$ & $40^{1}$ & $2.8 \pm 0.836^{\mathrm{fg}}$ & $3.2 \pm 0.167^{\mathrm{e}}$ & + \\
\hline MS+TDZ (2.0) & $63.33^{\mathrm{fg}}$ & $35^{\mathrm{k}}$ & $3.6 \pm 0.547^{\mathrm{def}}$ & $3.6 \pm 0.238^{\mathrm{de}}$ & ++ \\
\hline $\mathrm{MS}+\mathrm{KIN}(2.0)+\mathrm{NAA}(0.5)$ & $80.00^{\mathrm{ab}}$ & $15^{b}$ & $6.4 \pm 0.547^{b}$ & $5.7 \pm 0.132^{\mathrm{a}}$ & +++ \\
\hline $\mathrm{MS}+\mathrm{BAP}(2.0)+\mathrm{NAA}(0.5)$ & $83.33^{\mathrm{a}}$ & $7^{\mathrm{a}}$ & $10.6 \pm 0.547^{\mathrm{a}}$ & $6.7 \pm 0.101^{\mathrm{b}}$ & ++++ \\
\hline $\mathrm{MS}+\mathrm{TDZ}(2.0)+\mathrm{NAA}(0.5)$ & $76.66^{\mathrm{bc}}$ & $20^{\mathrm{e}}$ & $4.4 \pm 0.894^{\mathrm{d}}$ & $4.4 \pm 0.241^{\mathrm{c}}$ & +++ \\
\hline
\end{tabular}

Response: - (No response), + (Very poor), ++ (Poor), +++ (Good) and ++++ (Very good).

Data generated from three independent experiments $(n=30)$ and “ \pm " values represent standard deviation (SE).

Table 3: Effect of IAA and IBA on in vitro rooting of $V$. canescens

\begin{tabular}{|c|c|c|c|c|c|}
\hline $\begin{array}{l}\text { Medium + plant growth } \\
\text { regulators (mg/l) }\end{array}$ & $\begin{array}{c}\text { Root } \text { regeneration } \\
(\%)\end{array}$ & $\begin{array}{l}\text { Average no. } \\
\text { of days }\end{array}$ & $\begin{array}{c}\text { Mean no. of roots/shoot } \\
\pm \mathrm{SE}\end{array}$ & $\begin{array}{c}\text { Mean length of Root } \\
\pm \mathrm{SE}(\mathrm{cm})\end{array}$ & Response \\
\hline 1/2MS & $0.00^{\mathrm{j}}$ & $0^{\mathrm{i}}$ & $0^{f}$ & $0^{\mathrm{h}}$ & - \\
\hline 1/2MS+IAA (1.0) & $16.66^{\mathrm{hi}}$ & $21^{\mathrm{e}}$ & $1.8 \pm 0.447^{\mathrm{de}}$ & $1.48 \pm 0.148^{\mathrm{d}}$ & + \\
\hline 1/2MS+IAA (2.0) & $43.33^{\mathrm{fg}}$ & $14^{\mathrm{c}}$ & $2.8 \pm 0.836^{\mathrm{cd}}$ & $2.16 \pm 0.114^{\mathrm{b}}$ & + \\
\hline 1/2MS+IAA (3.0) & $50.00^{\mathrm{ef}}$ & $14^{\mathrm{c}}$ & $2.6 \pm 0.894^{\mathrm{cd}}$ & $2.04 \pm 0.134^{\mathrm{b}}$ & ++ \\
\hline 1/2MS+IBA (1.0) & $73.33^{\mathrm{b}}$ & $7^{\mathrm{b}}$ & $5.2 \pm 0.836^{\mathrm{ab}}$ & $1.74 \pm 0.167^{\mathrm{c}}$ & ++++ \\
\hline $1 / 2 \mathrm{MS}+\mathrm{IBA}(2.0)$ & $86.66^{\mathrm{a}}$ & $6^{\mathrm{a}}$ & $5.8 \pm 1.095^{\mathrm{a}}$ & $2.42 \pm 0.074^{\mathrm{a}}$ & ++++ \\
\hline 1/2MS+IBA (3.0) & $73.33^{\mathrm{b}}$ & $6^{\mathrm{a}}$ & $3.4 \pm 0.547^{\mathrm{c}}$ & $2.42 \pm 0.132^{\mathrm{a}}$ & +++ \\
\hline MS & $0.00^{\mathrm{j}}$ & $0^{\mathrm{i}}$ & $0^{\mathrm{f}}$ & $0^{\mathrm{h}}$ & - \\
\hline MS+IAA (1.0) & $10.00^{\mathrm{i}}$ & $27^{\mathrm{h}}$ & $1.2 \pm 0.447^{\mathrm{e}}$ & $0.42 \pm 0.083^{\mathrm{g}}$ & + \\
\hline MS+IAA (2.0) & $20.00^{\mathrm{h}}$ & $25^{\mathrm{f}}$ & $2.4 \pm 1.140^{\mathrm{cd}}$ & $1.08 \pm 0.258^{\mathrm{e}}$ & + \\
\hline MS+IAA (3.0) & $36.66^{\mathrm{g}}$ & $26^{g}$ & $2.0 \pm 0.707^{\mathrm{de}}$ & $1.18 \pm 0.192^{\mathrm{e}}$ & + \\
\hline MS+IBA (1.0) & $53.33^{\text {de }}$ & $16^{\mathrm{d}}$ & $2.8 \pm 0.836^{\mathrm{cd}}$ & $0.64 \pm 0.167^{f}$ & ++ \\
\hline MS+IBA (2.0) & $66.66^{\mathrm{bc}}$ & $16^{d}$ & $4.6 \pm 1.516^{b}$ & $1.56 \pm 0.181^{\mathrm{cd}}$ & +++ \\
\hline MS+IBA (3.0) & $60.00^{\mathrm{cd}}$ & $14^{\mathrm{c}}$ & $2.6 \pm 0.547^{\mathrm{cd}}$ & $1.52 \pm 0.192^{\mathrm{d}}$ & ++ \\
\hline
\end{tabular}

Response: - (No response), + (Very poor), ++ (Poor), +++ (Good) and ++++ (Very good).

Data generated from three independent experiments $(n=30)$ and “ \pm " values represent standard deviation (SE). 


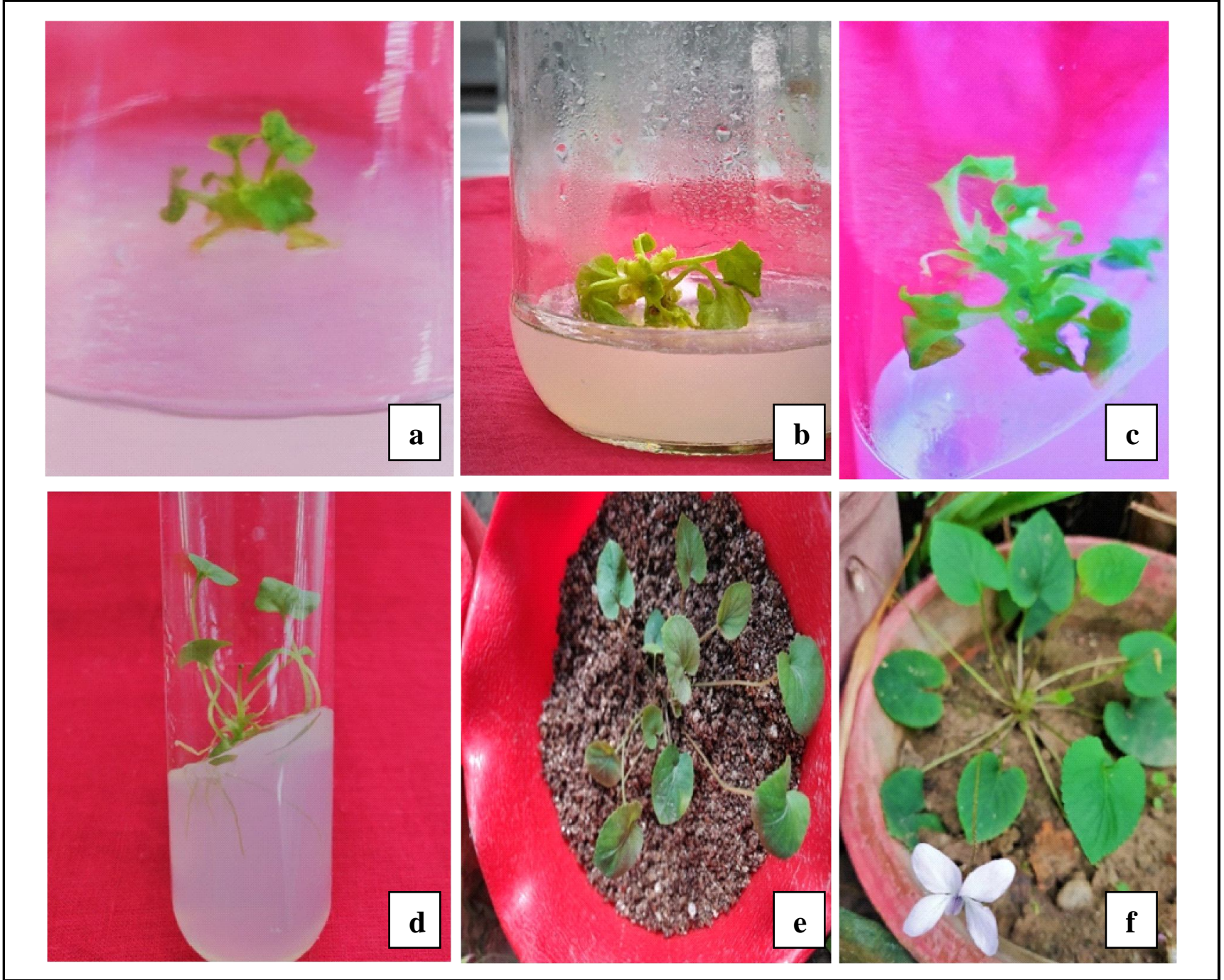

Figure 1: High-frequency plant regeneration from the cotyledonary node of Viola canescens Wall. ex Roxb. (a) Shoot bud initiation from a cotyledonary node after 3 weeks in culture on MS basal medium augmented with BAP (2.0) + NAA (0.5). (b.) Shoot regeneration with small callus after the $4^{\text {th }}$ week of inoculation in BAP $(2.0)+$ NAA (0.5). (c.) High frequency shoot proliferation after $5^{\text {th }}$ week on MS + BAP $(2.0)+$ NAA $(0.5)$. (d.) In vitro rooting in $1 / 2 \mathrm{MS}+$ IBA $(2.0 \mathrm{mg} / \mathrm{l})$ after 3 week in culture. (e.) Acclimatized plantlet in the plastic pot after 4 weeks of transfer. (f.) Well acclimatized plant showing flowering.

\subsection{Acclimatization and hardening}

Regenerated plantlets having healthy roots were extracted out of rooting media and cleaned properly to eliminate adhering medium and transferred to pots containing pre-soaked vermiculite and $1 / 2$ MS solution. Plantlets were preserved for 2 weeks inside the mist chamber to maintain high $(80 \%)$ humidity under diffused sunlight through greenhouse sheet of mist chamber in temperature $27 \pm 3^{\circ} \mathrm{C}$. After two weeks, pots were carried out of the mist chamber and placed outside under $80 \%$ shaded place for acclimatization to the natural environment. About $85 \%$ of regenerated plants survived in the field.

\section{Discussion}

The challenging task or main obstacle of plant tissue culture is using a nature grown plant which is highly prone to contamination as a source of explant for aseptic in vitro culturing (Sarasan et al., 2006). The first step of present investigation was carried out to standardized a protocol for seed sterilization using different sterilants $\left(\mathrm{H}_{2} \mathrm{O}_{2}, \mathrm{NaOCl}\right.$ and $\mathrm{HgCl}_{2}$ ). Out of three sterilants used, $\mathrm{HgCl}_{2}$ was found better in correlation to $\mathrm{NaOCl}$ and $\mathrm{H}_{2} \mathrm{O}_{2}$. A similar observation is described by $\mathrm{Xu}$ et al. (2005) for explant sterilization of Pinellia ternata (Thunb.) Breit, Maina et al. (2010) in Arachis hypogeal; Groach and Singh (2013) in Saussurea lappa. While $\mathrm{H}_{2} \mathrm{O}_{2}$ showed poor results with the maximum percentage of contamination and minimum percentage of survived explant as reported by Farooq et al. (2002) for surface sterilization of Annona squamosa.

In vitro establishment of cotyledonary node and shoot multiplication has been developed using basal MS media fortified with varied type of plant growth regulators, i.e., BAP, KIN and TDZ with different concentrations alone or in combination with NAA. The role of cytokinin is well known for induction and shoot proliferation (Kaloo et al., 2013; Groach et al., 2014). Seed germination potential was directly affected by the seeds' storage time after collection as well as 
sterilization treatments. Seeds stored for longer duration did not show any germination even after soaking in lukewarm water for $48 \mathrm{~h}$ (Goel et al., 2009). Freshly, collected seeds cultured within one week on fresh basal medium after pre-treatment with $1.0 \% \mathrm{HgCl}_{2}$ for 5 min (T9) showed a maximum survival rate and minimum percentage of contamination.

BAP found strongest in terms of the effect on shoot elongation and shoot number per explant, followed by KIN and TDZ at concentration $2.0 \mathrm{mg} / \mathrm{l}$. In an earlier study, MS medium supplemented with $2.0 \mathrm{mg} /$ 1 BAP were found significant for shoot multiplication in Andrographis paniculata (Shailaja et al., 2020). Equal concentrations of BAP and KIN were found optimum for effective shoots regeneration in Rubia cordifolia (Sharma et al., 2021). Adding a small concentration of NAA $(0.5 \mathrm{mg} / \mathrm{l})$ along with a high concentration of cytokinin significantly enhances explant regeneration, induction and shoot multiplication regeneration. Synergic result of using cytokinin with auxin has been found most promising for direct regeneration in many medicinal plant species like Brassica juncea (Guo et al., 2005), Mucuna pruriens (Faisal et al., 2006) and Vitex trifolia (Ahmad et al., 2013). On increasing concentration of cytokinin leads to vitrification, i.e., wilting and yellowing in color (Martin et al., 2006; Bhatia et al., 2008; Soni and Kaur, 2014). Overdose of auxin increased callus induction at the base of the cotyledonary node.

Half and full strength basal medium along with most frequently used auxins (IAA and IBA) were evaluated at different concentrations (1.0 - $3.0 \mathrm{mg} / \mathrm{l}$ ) for optimizing rooting response in in vitro raised shoots of $V$. canescens for complete plant regeneration. Half strength MS medium fortified with IBA at concentration $2.0 \mathrm{mg} / \mathrm{l}$ found to be good for regeneration of healthy and elongated roots as compare to IAA on the same concentration. The effectiveness of IBA for rooting have been documented in many plant species such as Tylophora indica (Faisal, Anis 2003), Aegle marmelos (Nayak and Behera, 2007), Streblus asper (Gadidasu et al., 2011), Viola patrinii (Chalageri and Babu, 2012) and Viola serpens (Jha et al., 2020). Present research became successful to acclimatize about $90 \%$ regenerated plants back to the environment.

\section{Conclusion}

A sterilization and direct in vitro propagation technique is standardized from cotyledonary node explants of $V$. canescens. We suggest the usage of $\mathrm{HgCl}_{2}$ for five minutes of seed sterilization and MS media augmented with $2.0 \mathrm{mg} / \mathrm{l}$ of BAP and $0.5 \mathrm{mg} / \mathrm{l}$ of NAA for multiple shoots regeneration from cotyledonary node. The present report contains skilled process for the conservation and direct in vitro propagation of a large number of $V$. canescens plants supposed with less somaclonal variation compared with indirect method.

\section{Acknowledgments}

We are grateful to Department of Botany, Kurukshetra University Kurukshetra and Plant Tissue Culture unit Sonti, Kurukshetra for providing all facilities and encouragement during research work. The Indian Council of Medical Research, New Delhi (ICMR), is duly acknowledged for sponsoring this project.

\section{Conflict of interest}

The authors declare no conflicts of interest relevant to this article.

\section{References}

Abbasi, A.M.; Khan, M.A.; Ahmad, M. and Zafar, M.(2011). Medicinal plant biodiversity of lesser Himalayas Pakistan. Springer Science and Business Media, New York.

Abbasi, A.M.; Khan, M.A.; Ahmed, M. and Zafar, M.(2010). Herbal medicines used to cure various ailments by the inhabitants of Abbottabad district, North West Frontier Province, Pakistan. Indian Journal of Traditional Knowledge, 9:175-83.

Adnan, M. and Hlscher D.(2010). Medicinal plant abundance in degraded and reforested sites in Northwest Pakistan. Mountain Res. Dev., 30: 25-32.

Ahmad, N.; Javed, S.B.; Khan, M.I. and Anis, M.(2013). Rapid plant regeneration and analysis of genetic fidelity in micropropagated plants of Vitex trifolia: An important medicinal plant. Acta Physiologiae Plantarum, 35(8):2493-2500.

Ajiboye, A.A.; Ajiboye, M.D. and Agboola, D.A. (2011). Influence of oven-dry heat $\left(40^{\circ} \mathrm{C}\right)$ treatment on germination of some Savanna tree seeds species: Tamarindus indica, Albizia lebbeck, Parkia biglobossa and Prosopis africana in Nigeria. International Research Journal of Plant Science, 2(9):276-280.

Ansari, M.H.R. and Ahmad, S. (2019). Herbs that heal: Natural remedies for health promotion and longevity. Ann. Phytomed., 8(1):7-18.

Badola, H.K. and Aitken, S.(2003). The Himalayas of India: A treasury of medicinal plants under siege. Biodiversity, 4(3):3-13.

Barkatullah, I.M.; Ali, N.; Muhammad, N. and Meryam, E.(2012). In vitro pharmacological study and preliminary phytochemical profile of Viola canescens Wall. Ex Roxb. Afr. J. Pharm. Pharmacol., 6:11421146.

Bhatia, R.; Singh, K.P. and Singh, M.C.(2008). Effect of growth regulators on regeneration from leaf derived callus and shoot proliferation in gerbera. Indian Journal of Horticulture, 65(3):312-316.

Burman, R.;Gunasekera, S.; Stromstedt, A.A. and Goransson, U.(2014). Chemistry and biology of cyclotides: Circular plant peptides outside the box. Journal of Natural Products, 77(3):724-736.

Chalageri, G. and Babu, U.V.(2012). In vitro plant regeneration via petiole callus of Viola patrinii and genetic fidelity assessment using RAPD markers. Turkish Journal of Botany, 36(4):358-368.

Chandra, D.; Kohli, G; Prasad, K.; Bisht, G; Punetha, V.D.; Khetwal, K.S.; Devrani, M.K. and Pandey, H.K.(2015). Phytochemical and ethnomedicinal uses of family Violaceae. Current Research in Chemistry, 7:44-52.

Dua, V. K.; Verma, G; Agarwal, D. D.; Kaiser, M. and Brun, R.(2011). Antiprotozoal activities of traditional medicinal plants from the Garhwal region of North West Himalaya, India. Journal of Ethnopharma cology, 136(1):123-128.

Duncan, D.B.(1955). Multiple range and multiple F-tests. Biometrics, 11:142

Faisal, M. and Anis, M.(2003). Rapid mass propagation of Tylophora indica Merrill via leaf callus culture. Plant Cell, Tissue and Organ Culture, 75(2):125-129.

Faisal, M.; Siddique, I. and Anis, M.(2006). In vitro rapid regeneration of plantlets from nodal explants of Mucuna pruriens: A valuable medicinal plant. Annals of Applied Biology, 148(1):1-6.

Farooq, S.A.; Farooq, T.T. and Rao, T.V.(2002). Micropropagation of Annona squamosa L. using nodal explants. Pakistan Journal of Biological Sciences, 5(1):43-46. 
Gadidasu, K.;Umate, P.; Aileni, M.; Kota, S.R.; Kokkirala, V.R.; Kasula, K. and Abbagani, S.(2011). Micropropagation of a Valuable ethnomedicinal plant Streblus asper Lour. Journal of Phytology, 3(2):18-23.

Gambley, R.L. and Dodd, W.A.(1990). An in vitro technique for the production de novo of multiple shoots in cotyledon explants of cucumber (Cucumis sativus L.). Plant Cell, Tissue and Organ Culture, 20(3): 177-183.

Goel, N.; Singh, N. and Saini, R.(2009). Efficient in vitro multiplication of Syrian Rue (Peganum harmala L.) using 6-benzylaminopurine preconditioned seedling explants. Nature and Science, 7(7):1545-0740.

Groach, R. and Singh, N.(2013). Influence of different chemicals on seeds sterilization and germination of Saussurea lappa Clarke under in vitro conditions. International Journal of Botany and Research, 3(5): 19-26.

Groach, R.; Hussain Dar, M.; Chand Badgal, K.; Pal, P.; Singh, N. and Yadav, K. (2014). Plantlet regeneration through indirect organogenesis of flame gold tree (Koelreuteria elegans Laxm.). Journal of Ornamental Plants, 4(3): 175-180.

Guo, D.P.; Zhu, Z.J.; Hu, X.X.; and Zheng, S.J.(2005). Effect of cytokinins on shoot regeneration from cotyledon and leaf segment of stem mustard (Brassica juncea var. tsatsai). Plant Cell, Tissue and Organ Culture, 83(1):123-127.

Hamayun, M.; Khan, S.A.; Kim, H.Y.; Na, C.I.; and Lee, I.J.(2006). Traditional knowledge and ex situ conservation of some threatened medicinal plants of Swat Kohistan, Pakistan. International Journal of Botany, 2(2):205-209

Haq, F.U. (2011). Conservation status of the critically endangered and endangered species in the Nandiar Khuwar catchment district Battagram, Pakistan. International Journal of Biodiversity and Conservation, 3(2):27-35.

Hussain, I.; Bano, A. and Ullah, F.(2011). Traditional drug therapies from various medicinal plants of central karakoram national park, GilgitBaltistan Pakistan. Pak. J. Bot., 43:79-84.

Jan, G.; Jan, F.G.; Hamayun, M.; Khan, K. and Khan, A. (2014). Diversity and conservation status of vascular plants of Dir Kohistan valley, Khyber Pakhtunkhwa Province. Journal of Biodiversity and Environmental Sciences, 5(1): 164-72.

Jha, S.R.; Naz, R.; Asif, A.; Okla, M.K.; Soufan, W.; Al-Ghamdi, A.A. and Ahmad, A. (2020). Development of an in vitro propagation protocol and a sequence characterized amplified region (SCAR) marker of Viola serpens Wall. ex Ging. Plants, 9(2):246.

Kaloo, Z.A.; Akhtar, R. And Zafrul-Haq, W.B.(2013). Effect of growth regulators on the in vitro multiplication of Viola odorata. Int. J. Med. Plant Res., 2(4):187-189.

Khajuria, A.K. and Bisht, N.S.(2018). Indirect in vitro regeneration of Viola canescens Wall. ex, Roxb. by using leaf calli. Plant Tissue Culture and Biotechnology, 28(2):215-222.

Khajuria, A.K.; Chandra, S.; Manhas, R.K. and Bisht, N.S.(2019). Effect of different PGRs on in vitro organogenesis in Viola canescens Wall. ex. Roxb. from petiole callus culture. Vegetos, 32(3):353-362.

Khan, M.A.; Ahmad, W.; Ahmad, M. and Nisar, M.(2017). Hepatoprotective effect of the solvent extracts of Viola canescens Wall. ex. Roxb. against $\mathrm{CCl}_{4}$ induced toxicity through antioxidant and membrane stabilizing activity. BMC Complementary and Alternative Medicine, 17(1): 10 .

Krishna, H.; Alizadeh, M.; Singh, D.; Singh, U.; Chauhan, N.; Eftekhari, M. and Sadh, R.K.(2016). Somaclonal variations and their applications in horticultural crops improvement. Biotech., 6(1):54.
Kumar, P. and Digvijay, S.(2014). Assessment of genetic diversity of Viola serpens Wall. in Himachal Pradesh using molecular markers. World Journal of Pharmaceutical Research, 3(2):2716-2726.

Li, J.T.; Deng, D.M.; Peng, G. T.; Deng, J.C.; Zhang, J. and Liao, B.(2010). Successful micropropagation of the cadmium hyperaccumulator Viola baoshanensis (Violaceae). International Journal of Phytoremediation, 12(8):761-771.

Maina, S.M.; Emongor, Q.; Sharma, K.K.; Gichuki, S.T.; Gathaara, M. and de Villiers, S.M.(2010). Surface sterilant effect on the regeneration efficiency from cotyledon explants of groundnut (Arachis hypogea L.) varieties adapted to eastern and Southern Africa. African Journal of Biotechnology, 9(20):2866-2871.

Martin, G.; Geetha, S.P.; Raja, S.S.; Raghu, A.V.; Balachandran, I. and Ravindran, P.N. (2006). An efficient micropropagation system for Celastrus paniculatus Willd.: A vulnerable medicinal plant. Journal of Forest Research, 11(6):461-465.

Masood, M.; Arshad, M.; Asif, S. and Chaudhari, S.K. (2014). Viola canescens: Herbal wealth to be conserved. Journal of Botany, pp:1-6.

McCauley, R.A. and Ballard Jr, H.E.(2013). Viola calcicola (Violaceae): a new endemic violet from the Guadalupe Mountains of New Mexico and Texas. Journal of the Botanical Research Institute of Texas, 7(1): 9-20.

Mokhtari, A.; Zarei, M.; Samsamzadeh. B. and Moradi, K. (2016). Interactive effects of plant growth regulators and explants on direct shoot regeneration of Viola odorata. Biol. Tech., 97(1):33-39.

Murashige, T. and Skoog, F.(1962). A revised medium for rapid growth and bio assays with tobacco tissue cultures. Physiologia Plant arum, 15(3):473-497.

Naeem, M.; Naveed, I.; Naqvi, S.M.S. and Mahmood, T.(2013). Standardization of tissue culture conditions and estimation of free scavenging activity in Viola odorata L. Pak. J. Bot., 45:197-202.

Nayak, P.; Behera, P.R. and Manikkannan, T.(2007). High frequency plantlet regeneration from cotyledonary node cultures of Aegle marmelos (L.) Corr. In vitro cellular and developmental biology. Plant, 43(3): 231-236.

Raja, R.; Bokhari, T.Z; Younis, U. and Dasti, A.A.(2014). Multivariate analysis of vegetation in wet temperate forests of Pakistan. Journal of Pharmacy and Biological Sciences, 1:54-59.

Rana, P.K.; Kumar, P.; Singhal, V.K. and Rana, J.C.(2014). Uses of local plant biodiversity among the tribal communities of Pangi Valley of district Chamba in cold desert Himalaya, India. The Scientific World Journal, pp:1-15.

Rani, S.; Rana, J.C. and Rana, P.K.(2013). Ethnomedicinal plants of Chamba district, Himachal Pradesh, India. Journal of Medicinal Plants Research, 7(42):3147-3157.

Razzaq, A.; Hadi, F.; Rashid, A.; Ibrar, M. and Ali, U.(2015). Exploration of medicinal plants and their conservation status at higher altitude of district Shangla, Khyber Pakhtunkhwa, Pakistan. Am. Eurasian J. Agric. Environ. Sci., 15:328-31.

Sagar, R.; Dumka, V.K.; Singh H. and Singla, S. (2018). Evaluation of antipyretic, muscle relaxant and neurobehavioural activities of various leaf extracts of Pongamia pinnata L. Ann. Phytomed., 7(2):98-101.

Saima, S.; Dasti, A.A.; Hussain, F.; Wazir, S.M. and Malik, S.A.(2009). Floristic compositions along an $18-\mathrm{km}$ long transect in ayubia National Park district Abbottabad, Pakistan. Pak. J. Bot, 41(5):2115-2127.

Sarasan, V.; Cripps, R.; Ramsay, M. M.; Atherton, C.;McMichen, M.; Prendergast, G. and Rowntree, J.K.(2006). Conservation in vitro of threatened plantsprogress in the past decade. In vitro Cellular and Developmental Biology Plant, 42(3):206-214. 
Shah, S.; Ram, J.; Pala, N.A.; Tripathi, P. and Kumar, M.(2014). Medicinal plant wealth of oak dominated forests in Nainital catchment area of Uttarakhand. Academia. J. Med. Plant, 2(1):006-13.

Shailaja, A.; Srinath, M.; Bindu, B.B.V. and Giri, C.C.(2020). Innovative technique for rapid in vitro multiplication of rootless shoots in Andrographis paniculata (Burm. f) Nees: A plant with immense pharmaceutical value. Ann. Phytomed., 9(1):98-106.

Sharma, A.; Shukla, S.; Quasim, A.; Patel, M. K.; Kumar, R.; Chaurasia, O.P. and Saxena, S. (2021).In vitro propagation, callus culture and phytochemical profiling of Manjishtha-A invaluable medicinal species of LehLadakh. Ann. Phytomed., 10(1):230-241.

Shinwari, M.I. and Shinwari, M.I.(2010). Botanical diversity in Pakistan; pas present and future. World Environmental Day-2010, pp:85-104.

Singh, M.; Sharma, C. and Lal, B. (2005). Species specific DNA sequences and their utilization in identification of Viola species and authentication of "banafsha" by polymerase chain reaction. U.S. Patent No. 6,924,127, B2. Washington, DC: U.S. Patent and Trademark Office.

Soni, M. and Kaur, R.(2014). Rapid in vitro propagation, conservation and analysis of genetic stability of Viola pilosa. Physiology and Molecular Biology of Plants, 20(1):95-101.

Venkatachalam, P.; Jinu, U.; Sangeetha, P.; Geetha, N. and Sahi, S.V.(2018). High frequency plant regeneration from cotyledonary node explants of Cucumis sativus L. cultivar 'Green Long'via adventitious shoot organogenesis and assessment of genetic fidelity by RAPD-PCR technology. 3 Biotech, 8(1):60.

Xu, T.; Zhang, L.; Sun, X. and Tang, K.(2005). Efficient in vitro plant regeneration of Pinellia ternata (Thunb) Breit. Acta Biol. Crac. Ser. Bot., 2:27-32.

Zayova, E.; Vassilevska Ivanova, R.; Kraptchev, B. and Stoeva, D. (2010). Somaclonal variations through indirect organogenesis in eggplant (Solanum melongena L.). Biological Diversity and Conservation, 3(3): $1-5$.

Kavita Rani, Rameshwar Groach, Jitender Sharma and Narender Singh (2021). In vitro direct multiplication of Viola canescens Wall. ex Roxb.: An important medicinal plant. Ann. Phytomed., 10(2):200-207. http://dx.doi.org/ 10.21276/ap.2021.10.2.28 